\title{
Vitrification of Cesium-Laden Organic Ion Exchange Resin in a Stirred Melter
}

by

C. A Cicero-Herman

Westinghouse Savannah River Company

Savannah River Site

Aiken, South Carolina 29808

T. N. Sargent

T. J. Overcamp

D. F. Bickford

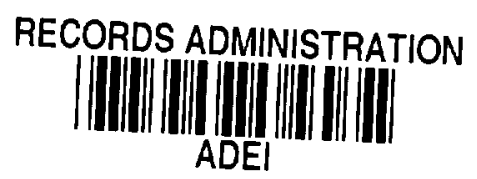

A document prepared for NUCLEAR TECHNOLOGY JOURNAL at , , from - .

DOE Contract No. DE-AC09-96SR18500

This paper was prepared in connection with work done under the above contract number with the U. S. Department of Energy. By acceptance of this paper, the publisher and/or recipient acknowledges the U. S. Government's right to retain a nonexclusive, royalty-free license in and to any copyright covering this paper, along with the right to reproduce and to authorize others to reproduce all or part of the copyrighted paper. 


\section{DISCLAIMER}

This report was prepared as an account of work sponsored by an agency of the United States Government. Neither the United States Government nor any agency thereof, nor any of their employees, makes any warranty, express or implied, or assumes any legal liability or responsibility for the accuracy, completeness, or usefulness of any information, apparatus, product, or process disclosed, or represents that its use would not infringe privately owned rights. Reference herein to any specific commercial product, process, or service by trade name, trademark, manufacturer, or otherwise does not necessarily constitute or imply its endorsement, recommendation, or favoring by the United States Government or any agency thereof. The views and opinions of authors expressed herein do not necessarily state or reflect those of the United States Government or any agency thereof.

This report has been reproduced directly from the best available copy.

Available to DOE and DOE contractors from the Office of Scientific and Technical Information, P.O. Box 62, Oak Ridge, TN 37831; prices available from (615) 576-8401.

Available to the public from the National Technical Information Service, U.S. Department of Commerce, 5285 Port Royal Road, Springfield, VA 22161. 
WSRC-MS-97-0565

Revision 0

Keywords: vitrification, glass, ion exchange resin

\section{VITRIFICATION OF CESIUM-LADEN ION EXCHANGE RESIN IN A STTRRED MELTER (U)}

by

Thomas N. Sargent, Jr. and Thomas J. Overcamp

Clemson University

Environmental Systcms Engineering

342 Computer Court

Anderson, SC 29625

Connie A. Cicero-Herman and Dennis F. Bickford

Westinghouse Savannah River Company

Savannah River Technology Center

Aiken, SC 29808

A Paper Proposed for Publication in Nuclear Technology magazine, which is published by the American Nuclear Society. Dr. William Vogelsang, who is the editor of the magazine, has been contacted about the submittal of this paper. WSRC would like to pay the publication costs. Paper should be approximately $4-5$ pages and cost is $\$ 135$ per page. Mailing address is 555 North Kensington Ave., La Grange Park, IL 60526.

This paper was prepared in connection with work done under the U.S. Department of Energy - Office of Technology Development Technical Task Plan No. SR1-3-20-04. By acceptance of this paper, the publisher and/or recipient acknowledges the U.S. Government's right to retain a non-exclusive, royalty-free license in and to any copyright covering this paper, along with the right to reproduce and to authorize others to reproduce all or part of the copyrighted paper. 


\section{VITRIFICATION OF CESIUM-LADEN ORGANIC ION EXCHANGE RESIN IN A}

STIRRED MELTER

THOMAS N. SARGENT, Jr., and THOMAS J. OVERCAMP,

Clemson University

Environmental Systems Engineering

342 Computer Court

Anderson, South Carolina 29625

DENNIS F. BICKFORD and CONNIE CICERO-HERMAN,

Westinghouse Savannah River Co.

Savannah River Technology Center

Aiken, SC 29808

Corresponding author:

THOMAS J. OVERCAMP

Clemson University

Environmental Systems Engineering

342 Computer Court

Anderson, South Carolina 29625-6510

PHONE: (864) 656-5573

FAX: (864) 656-0672

tjvrc@clemson.edu

Total pages $=19$

Total figures $=2$

Total tables $=3$ 
VITRIFICATION OF CESIUM-LADEN ORGANIC ION EXCHANGE RESIN IN A STIRRED MELTER

THOMAS N. SARGENT, Jr., and THOMAS J. OVERCAMP, Clemson University

Environmental Systems Engineering

342 Computer Court

Anderson, South Carolina 29625

DENNIS F. BICKFORD and CONNIE CICERO-HERMAN, Westinghouse Savannah River Co.

Savannah River Technology Center

Aiken, SC 29808

Tests were conducted using a stirred-tank melter to vitrify nonradioactive, cesium-laden organic ion exchange resin. This resin, which is highly effective in removing cesium from solution, was developed to replace the complex sodium tetraphenylborate precipitation process used on the feed sent to the Defense Waste Processing Facility at the Savannah River Site to remove cesium-137 from a wastewater solution. Lower bound estimates of overall cesium retention in the glass range from 70.5 to $73.9 \%$. Only 2.1 to $4.3 \%$ of the cesium was emitted from the melter. Since between 21.8 to $27.4 \%$. of the cesium was not recovered or accounted for, the overall cesium retention may have been much higher.

KEY WORDS: Vitrification, ion exchange resins, cesium

\section{INTRODUCTION}

High-level radioactive waste $(\mathrm{HLW})$ is the waste resulting from the processing of irradiated nuclear fuel. After ten to twenty years of storage, cesium-137 is one of the major sources of beta and gamma radiation. In the United States, HLW from nuclear weapons programs was neutralized and stored as a sludge with a salt layer and supernatant. Because cesium-137 is water soluble, it partitions to the supernatant instead of the sludge or salt layer, which contain the bulk of the other radionuclides. 
At the Savannah River Site (SRS), precipitation using sodium tetraphenylborate (NaTPB) is used to remove cesium from the supernatant so that it can be fed to the HLW melter. Since direct addition of NaTPB would burden the melter with a large quantity of organic material, NaTPB is hydrolyzed and reduced with formic acid to produce a benzene waste requiring further treatment. Organic compounds in the feed promote reducing conditions in the glass. A more reduced HLW glass is often less durable because reduced iron, $\mathrm{Fe}^{2+}$, acts as a network modifier. In contrast, $\mathrm{Fe}^{3+}$ is a network former that improves glass durability.

A resorcinol-formaldehyde cation exchange resin was developed at the SRS to remove cesium. Use of this resin would have several advantages over the NaTPB process, including lowering the amount of alkali metals fed to the melter, allowing the boron content of the glass to be more easily controlled, and eliminating the benzene waste stream. $(1, \underline{2})$

A proposed disposal method for spent resin is feeding it with frit and HLW sludge directly to a HLW melter. In preliminary tests, problems occurred in feeding the resin to a slurry-fed melter. The resin formed a crust on the melter's surface increasing the time for incorporation in the melt. The resin also promoted reducing conditions that could increase cesium volatility and result in a less durable glass.(3)

The use of a stirred-tank melter may help overcome these problems. Since the entire melt is mixed by an impeller, crust formation can be prevented. Agitation may also increase oxygen transfer to the melt and avoid a highly reduced glass.

The goal of this research was a feasibility study for vitrifying the organic ion exchange resin in a stirred-tank melter. Tests were conducted to determine the fate of cesium including the feed, exit glass, and offgas streams and to assess any impact of feeding the resin on the melter or its performance. 


\section{BACKGROUND \\ Ion Exchange Process}

The cation exchange resin, developed at Savannah River Technology Center (SRTC), has a cesium capacity four times greater than the best commercial resin.(2) If it were to replace the NaTPB precipitate process, it would decrease the complexity of the cesium decontamination process, lower the amount of organic compounds fed to the melter, and eliminate the benzene waste stream.

To determine if this resin could be fed to a melter, Bibler et al.(3) used an $18 \mathrm{~kg}$ glass capacity, ceramic-lined, Joule-heated melter at a temperature of $1150^{\circ} \mathrm{C}$. Three runs were performed. The first run fed simulated sludge and frit 165; the remaining runs fed a mixture of frit 165 , sludge, and resin. The schedule for the first two runs consisted of pouring for sixteen hours during the first two days and eight hours during the third day with the melter idling for the remaining hours. The schedule for the third run was a continuous run lasting fifty-three hours. Each run produced about $144 \mathrm{~kg}$ of glass.

No effects on melter operation, such as shorting due to conductive species, plugging of the offgas system, or difficulties in pouring the melt, were caused by resin addition. On the other hand, the redox ratio, defined as the ratio of $\mathrm{Fe}^{2+}$ to $\mathrm{Fe}^{\text {Total }}$ in the glass, increased when resin was added. This indicated the glass was becoming more reduced. The glass also was less durable due to feeding the resin. Because the last run did not have an idling period where oxygen could transfer to the melt as in the first two runs, this ratio was highest during the third run.

Overcamp et al.(4) performed crucible tests to determine cesium retention in glass feeds containing either activated carbon or resorcinol-formaldehyde resin. They found that the reducing power of the organic resin was approximately four times less on a mass basis than activated carbon. The average cesium retention for glass samples with cesium-laden resin as a reducing agent was $74.7 \%$ with a standard deviation of $5.5 \%$. The average cesium retention for glass samples that used activated carbon as a reducing agent was $66.8 \%$ with a standard deviation of $5.2 \%$. There was no correlation between the final redox ratio of the glass and cesium retention. 


\section{MATERIALS AND METHODS}

\section{Equipment}

\section{Stirred-Tank Melter}

The stirred-tank glass melter used in this research was the Stir-Melter model WV-0.25. A cutaway of the melter is shown in Fig. 1. It was a Joule-heated melter with a $10 \mathrm{~kW}$ power supply. The $152 \times 152 \times 305 \mathrm{~mm}$ vessel was constructed of Inconel ${ }^{\mathrm{TM}} 601$. Heating elements with a $7 \mathrm{~kW}$ power supply surround the vessel. These auxiliary heaters were used for start-up and to assist in maintaining melter temperatures. An Inconel 690 impeller mixed the glass and served as one electrode in the Joule-heating circuit. The height and rotational speed of the impeller could be varied. Glass-making slurry was fed through ports at the top of the melter vessel and was rapidly incorporated into the melt. When the molten glass had a sufficient hydrostatic head, glass flowed through an opening in the bottom of the tank. Then it flowed upwards through a channel in the corner of the vessel, over a weir located $152 \mathrm{~mm}$ from the bottom of the vessel, and then down the drain tube.(吕)

\section{Gas Sparging System}

In this study, the melter was equipped with a gas sparging system consisting of a 1/4" Inconel 601 pipe. This pipe entered at the top of the melter's tank, ran down along a corner edge, and across the bottom of the melter until it was directly under the impeller. Oxygen from a gas cylinder flowed through the pipe and bubbled beneath the impeller.

\section{Feed System}

In the oxygen transfer tests, slurry in a large mixing tank was fed to the melter using a peristaltic pump through a water-cooled slurry feed nozzle. In the tests with resin, slurry from the mixing tank and cesium-laden ion exchange resin were mixed in a $20 \mathrm{~L}$ bucket and fed from this bucket to the melter through a water-cooled slurry feed nozzle using a peristaltic pump. 


\section{Offgas Control System}

A positive-displacement, rotary blower pulled gases evolving from the feed and any air leaking into the melter through a $2 "$ schedule 10 stainless-steel pipe. A sampling port was installed approximately $1 \mathrm{~m}$ above the melter. The gases then flowed through a 1 " schedule 10 stainless-steel pipe to a spray quencher. Approximately $1 \mathrm{~L} / \mathrm{min}$ of water was sprayed into the flow to lower the temperature and scrub larger particles. The gas then was bubbled through a perforated pipe into the jet bubbler tank with an operational volume of approximately $92 \mathrm{~L}$. The gas then traveled through a $152 \mathrm{~mm}$ diameter countercurrent tower packed to a level of $1.5 \mathrm{~m}$ with $12.7 \mathrm{~mm}$ glass Raschig rings. The liquid flow to the tower was approximately 4 to $8 \mathrm{~L} / \mathrm{min}$. The effluent liquid was pumped back to a $325 \mathrm{~L}$ reservoir.

\section{Materials}

The slurry provided by SRTC in this research was a HLW surrogate slurry for the SRS Defense Waste Processing Facility (DWPF) melter. The slurry was approximately 35 to $40 \%$ by mass solids. It consisted of three components. The first was a surrogate metal oxide sludge (Optima Chemicals, Inc., Douglas, GA) similar to SRS HLW sludge. The second was frit 202 (Cataphote, Inc., Flowood, MS), a borosilicate glass frit. The third was simulated precipitate hydrolysis aqueous (PHA) product. If the ion exchange process replaced the NaTPB precipitation process, PHA material would not be present in the slurry. Except for the small amount of formic acid in the simulated PHA material, no other organic material or carbon was present in the slurry.

The resin was supplied by SRTC in two forms. The first form, used in the oxygen transfer tests, was dry and not loaded with cesium. The second, a moist resin loaded with nonradioactive cesium, was used in the vitrification test. Based on drying in an oven at $100^{\circ} \mathrm{C}$, it was approximately $38.4 \%$ solids. The ratio of cesium was 0.187 (g cesium)/(g oven-dried resin). 


\section{Oxygen Transfer Tests \\ Experimental Procedure}

The oxygen transfer test was conducted using continuous slurry flow. The melter temperature was $1070^{\circ} \mathrm{C}$. The oxygen sparge flow rate was $1 \mathrm{~L} / \mathrm{min}$. Slurry was fed at 50 $\mathrm{mL} / \mathrm{min}$. When the melter was operating at steady-state conditions, $300 \mathrm{~g}$ of resin was fed in 30 to $100 \mathrm{~g}$ portions to the melt to increase the $\mathrm{Fe}^{2+} / \mathrm{Fe}^{\text {Total }}$ ratio. The melter operation was continued with slurry feed containing the resin. During the run, samples of molten glass from the molten surface and from the exit glass were taken. These samples were analyzed to determine the $\mathrm{Fe}^{2+} / \mathrm{Fe}^{\text {Total }}$ ratio.

\section{Glass Sampling Procedure}

Glass was sampled both from the surface of the melt and from the exit glass stream during the testing. Outlet samples were taken by catching the glass stream on a stainless-steel plate. This glass was cooled in the air and then stored in labeled plastic vials. To obtain a sample from the melter, an Inconel ${ }^{\mathrm{TM}}$ welding rod was inserted approximately $4 \mathrm{~cm}$ beneath the surface of the melt, removed, and cooled in the air. The sample was removed from the rod by covering the glass with a paper towel and lightly tapping with a hammer.

\section{Vitrification of Ion Exchange Resin Experimental Procedure}

The melter was filled to a depth of approximately $150 \mathrm{~mm}$ with glass having a nominal $8.6 \%$ by mass elemental iron content. The melter and auxiliary temperature controllers were adjusted to $1070^{\circ} \mathrm{C}$ and $1045^{\circ} \mathrm{C}$, respectively. The oxygen sparger was turned on at a rate of 1.2 $\mathrm{L} / \mathrm{min}$. The packed tower scrubber and the jet bubbler tanks were filled with tap water. After the scrubber water circulated through the packed column for approximately thirty minutes, three scrubber solution sample blanks were taken. Three sample blanks were also taken from the jet bubbler tank. The feed bucket was filled at a ratio of $26.08 \mathrm{~g}$ of the moist resin loaded with nonradioactive cesium to $1 \mathrm{~L}$ of slurry. A small mixer kept the slurry and resin in suspension. 
Samples were taken from this initial slurry mixture. When the melter reached the setpoint temperatures, slurry was added to the melter at a rate of $51 \mathrm{~mL} / \mathrm{min}$. During the run, the level in the feed bucket was maintained by adding the correct proportions of resin and slurry.

\section{Sampling Procedure}

Replicate samples of the initial batch and the final batch feed slurry were taken from the slurry feed nozzle. During the run, samples from the packed column and the jet bubbler tanks were taken hourly from the effluent pumped from the tank. Since the tank was mixed by bubbling, these samples should have been representative of the average concentration in the tank. Samples from effluent of the packed tower were taken from the flow pumped back into the reservoir. Samples of exit glass were taken approximately every thirty minutes.

After about 3 melter volumes of glass were produced, offgas sampling was conducted using a modified version of the EPA Method 29 sampling train.(6) Although this method has not been validated for cesium, it was felt that it should be accurate due to the high solubility of most common cesium compounds. Since mercury was not present in the feed, the two permanganate impingers for mercury were replaced with additional $\mathrm{HNO}_{3} / \mathrm{H}_{2} \mathrm{O}_{2}$ impingers.

\section{Analytical Methods.}

Redox determination of all glass samples was performed using colorimetric analysis.(7)

Glass and feed samples were chemically analyzed by Corning Laboratory Services, Corning, NY, using inductively coupled plasma emission spectroscopy (ICPES) and flame atomic absorption (AA) spectroscopy. Liquid samples were analyzed for cesium by SRTC using flame AA. The Method 29 samples were analyzed by Oxford Laboratories, Wilmington, NC.

\section{RESULTS AND DISCUSSION Oxygen Transfer Tests}

The continuous feed test was performed to evaluate the oxygen transfer when slurry was fed to the melter. After $300 \mathrm{~g}$ of resin had been added, the melt was continuously fed slurry with 
resin and allowed to reoxidize. Considering the total iron content of the glass in the melter and the redox ratio, the total moles of oxygen as $\mathrm{Fe}_{2} \mathrm{O}_{3}$ are shown in Fig. 2. The approximate oxygen transfer rate was $0.0096\left(\mathrm{~mol} \mathrm{O}_{2}\right) / \mathrm{min}$. Based on the crucible study,(4) this would accommodate a resin feed rate of 0.46 ( $\mathrm{g}$ moist resin) $/ \mathrm{min}$.

\section{Vitrification of Ion Exchange Resin}

A mixture of nonradioactive cesium-laden resin and the slurry was fed to the melter for 23 hours with 3.1 tank volumes of glass produced. After approximately one hour, the $\mathrm{Fe}^{2+} / \mathrm{Fe}^{\text {Total }}$ ratio was nearly constant with an average value of 0.176 . For HLW glass, this ratio is acceptable. At the end of the run, no corrosion or other damage to the impeller or melter tank was noted.

The samples taken at the beginning and at the end of the test were analyzed for major oxides and loss on ignition (LOI) at $850^{\circ} \mathrm{C}$. The data, given in Table $\mathrm{I}$, show that the cesium concentration of the feed slurry increased over the course of the run. The mass percent of $\mathrm{Cs}_{2} \mathrm{O}$ in the dried slurry solids should have been approximately $0.464 \%$ by mass. The initial concentration was $0.26 \%$ by mass $\mathrm{Cs}_{2} \mathrm{O}$, which was lower than predicted. The final concentration was $0.55 \%$ by mass $\mathrm{Cs}_{2} \mathrm{O}$, which was higher than predicted. This could have been due to inadequate mixing in the feed bucket or a batching error.

To calculate the cesium fed to the melter, all cesium used in making the slurry batches minus the cesium remaining in the bucket after the test was estimated. The total moist resin used in making the feed was $2036 \mathrm{~g}$. Since the resin was $38.4 \%$ oven-dried solids and loaded with cesium at a mass ratio of $(0.187 \mathrm{~g} \mathrm{Cs}) /(\mathrm{g}$ oven-dried resin $)$, the total cesium used in making the feed mixture was $146.20 \mathrm{~g}$. Because $20.18 \mathrm{~kg}$ of feed was left in the bucket, some of this cesium was not fed to the melter. Since the cesium analyses of the slurry do not agree with that predicted based on the quantities of resin and slurry used in making the batch, the cesium remaining in the bucket after the test can be estimated using either the predicted mass percentage in the final slurry or the final measurement of the $\mathrm{Cs}_{2} \mathrm{O}$ concentration. If the calculations are based on the predicted 
$\mathrm{Cs}_{2} \mathrm{O}$ in the feed mixture of $0.464 \%$ by mass and an LOI of $66.5 \%$, the cesium remaining in the bucket was $29.59 \mathrm{~g}$, and the cesium fed to the melter is estimated as $116.61 \mathrm{~g}$. If the final value of $0.55 \%$ by mass $\mathrm{Cs}_{2} \mathrm{O}$ is used, the cesium remaining in the bucket was $35.07 \mathrm{~g}$ resulting in an estimate of $111.13 \mathrm{~g}$ of cesium fed to the melter, or approximately $5 \%$ uncertainty.

Table II shows the analyses of glasses taken at four times during the run. The temporal changes in cesium concentration resemble those expected in a continuously stirred-tank reactor.

To calculate the total cesium retained in the glass, the average mass percentage of $\mathrm{Cs}_{2} \mathrm{O}$ in the glass collected in the crucibles and the mass percentage of $\mathrm{Cs}_{2} \mathrm{O}$ in the glass remaining in the vessel after the run was estimated. The sum of the cesium in the collected glass and in the glass remaining in the melter was the total cesium retained in the glass.

The average cesium oxide concentration in the glass produced, calculated by dividing the area under the curve by the total run time, was $0.218 \%$ by mass $\mathrm{Cs}_{2} \mathrm{O}$. Since the total glass collected was $25.87 \mathrm{~kg}$, the mass was $56.40 \mathrm{~g}$ of $\mathrm{Cs}_{2} \mathrm{O}$ or $53.20 \mathrm{~g}$ of elemental cesium.

The cesium in the glass remaining in the vessel was calculated by multiplying the final mass percentage of $\mathrm{Cs}_{2} \mathrm{O}$ in the exit glass by the mass of glass remaining in the vessel. The last measured concentration of $\mathrm{Cs}_{2} \mathrm{O}$ was $0.347 \%$ by mass. Since $8.85 \mathrm{~kg}$ glass remained in the vessel, the elemental cesium remaining was $28.97 \mathrm{~g}$. The total amount of cesium in the glass was estimated to be $82.17 \mathrm{~g}$. This is between $70.5 \%$ and $73.9 \%$ of the cesium fed to the melter.

Duct deposits were cleaned from the offgas piping exiting the melter and the riser. The deposits were dark brown to black in color and had the texture of fine soot. There were some very small yellow particles mixed in with the soot-like material. A total of $12.70 \mathrm{~g}$ of deposit was collected containing approximately $0.14 \mathrm{~g}$ of elemental cesium.

Four samples of the jet bubbler tank effluent were filtered and analyzed. The results of the analyses are shown in Table III. Neglecting the anomalously high point at $670 \mathrm{~min}$, the elemental cesium in the exiting bubbler solution was $1.87 \mathrm{~g}$. The final concentration of cesium in the jet bubbler tank was $2.23(\mathrm{mg} \mathrm{Cs}) / \mathrm{L}$. Since the solution remaining in the tank was $91.8 \mathrm{~L}$, the total 
cesium remaining in the tank after the test was $0.205 \mathrm{~g}$. The total elemental cesium captured in the bubbler was the sum or $2.07 \mathrm{~g}$.

When the samples were taken from the effluent of the jet bubbler tank, there were small particles present in the solution. Since solids were present in the jet bubbler tank at the beginning of the run, recovered solids were not analyzed.

Four samples of the water from the packed tower were taken at the exit of the column. These samples had no detectable solids. The analyses are shown in Table III. The cesium concentration increased approximately linearly with time. The elemental cesium captured by the scrubber column estimated by multiplying the total volume of solution in the scrubber tank by its final concentration was $0.22 \mathrm{~g}$.

Neglecting any cesium in particulate form filtered from the bubbler solution, the total emitted was the sum of cesium in offgas deposits, the filtered bubbler solution, and the packed column scrubber solution. This is $2.43 \mathrm{~g}$, which only accounts for 2.1 to $2.2 \%$ of the total elemental cesium fed to the melter.

An alternative estimate of the cesium emissions is the sum of the cesium in the Method 29 emissions and in the offgas deposits. The estimated elemental cesium emissions were $0.206 \mathrm{~g} \mathrm{Cs}$ per hour. If these emissions were constant over the 1385 minutes of the trial, the cesium emissions would have been $4.76 \mathrm{~g}$. Adding in the cesium recovered in the offgas deposits, this gives an estimate of $4.90 \mathrm{~g}$ for the total cesium emissions. Even though this value is about twice the $2.43 \mathrm{~g}$ obtained in the first method, it only accounts for 4.1 to $4.3 \%$ of the cesium fed to the melter.

The percentage difference between the cesium fed to the melter and the sum of the cesium retained in the glass or emitted from the melter was 21.8 to $27.4 \%$. There are several plausible reasons for this unaccounted cesium. First, cesium could have deposited on the walls of the melter's plenum, which were not sampled. Secondly, some errors in the feed, glass, offgas, or other chemical analyses may have occurred because of the small amount of cesium present. 


\section{CONCLUSIONS AND RECOMMENDATIONS}

Both an oxygen transfer test and a test of the vitrification of cesium-laden resin were successfully conducted using a stirred melter. The oxygen transfer rate with a slurry feed rate of $50 \mathrm{~mL} / \mathrm{min}$, an oxygen sparging rate of $1 \mathrm{~L} / \mathrm{min}$, and impeller agitation was $0.0096\left(\mathrm{~mol} \mathrm{O}_{2}\right) / \mathrm{min}$.

The melter was successfully operated for 23 hours using a feed mixture of slurry and resin contaminated with nonradioactive cesium. There were no significant operational problems during the run. No damage to the Inconel melter or its impeller was noted after the run. At least 70.5 to $73.9 \%$ of the cesium fed to the melter was retained in the glass. Between 2.1 and $4.3 \%$ of the cesium was emitted. Since between 21.8 to $27.4 \%$ of the cesium was not recovered or accounted for, the overall cesium retention may have been much higher.

These promising results indicate that the ion exchange resin can be added along with HLW slurry feed in an oxygen-sparged, stirred tank melter.

\section{ACKNOWLEDGMENTS}

This research was funded by the United States Department of Energy's Environmental and Waste Management Office of Technology Development under technical task plan number SR1-320-04 in cooperation with the South Carolina Universities Research and Education Foundation (SCUREF) under Task Order 95 and contract number DE-AC09-89SR18035. Mr. Sargent is currently an environmental engineer with GeoSyntec Consultants in Atlanta, GA. Address correspondence to Dr. Overcamp. 


\section{REFERENCES}

1. J.P Bibler and R.M Wallace, "Preparation and Properties of a Cesium Specific

Resorcinol-Formaldehyde Ion Exchange Resin," DPST-87-647, E.I. du Pont de Nemours \& Co., Aiken, South Carolina (1987).

2. R.M Wallace and J.P Bibler, “An Improved Method for Decontaminating Soluble HighLevel Waste Using Ion Exchange," DPST-88-789, E.I. du Pont de Nemours \& Co., Aiken, South Carolina (1988).

3. N.E. Bibler, J.P. Bibler, M.K. Andrews, and C.M. Jantzen, "Initial Demonstration of the Vitrification of Nuclear Waste Sludge Containing an Organic Cs-Laden Ion Exchange Resin," WSRC-MS-91-465, Westinghouse Savannah River Co., Aiken, South Carolina (1991).

4. T.J. Overcamp, and T. N. Sargent, Jr., "Vitrification of Cesium-Laden Organic Ion Exchange Resin in a Stirred Melter," CU/VRL-96-003, Clemson University, Anderson, South Carolina (1996).

5. R.S. Richards, and V. Jain, "Rapid Stirred Melting of Simulated West Valley High-Level Waste," Environmental and Waste Management Issues in the Ceramic Industry, Mellinger, G. B., ed., Ceramic Transactions, v. 39, American Ceramic Society, Westerville, OH, 1994, pp. 229238 (1993).

6. US EPA, "Standards of Performance for New Stationary Sources National Emission Standards for Hazardous Air Pollution: Addition of Method 29 to Appendix A of part 60 and Amendments to Method 101A of Appendix B of Part 61," Federal Register, 61: 81, 1826018281 (1996). 
7. E. Baumann, C.J. Coleman, D.G. Karraker, and W.H. Scott, "Colorimetric Determination of Fe(II)/Fe(III) Ratio in Glass," DP-MS-87-18, E.I. du Pont de Nemours \& Co.. Aiken, South Carolina (1987). 


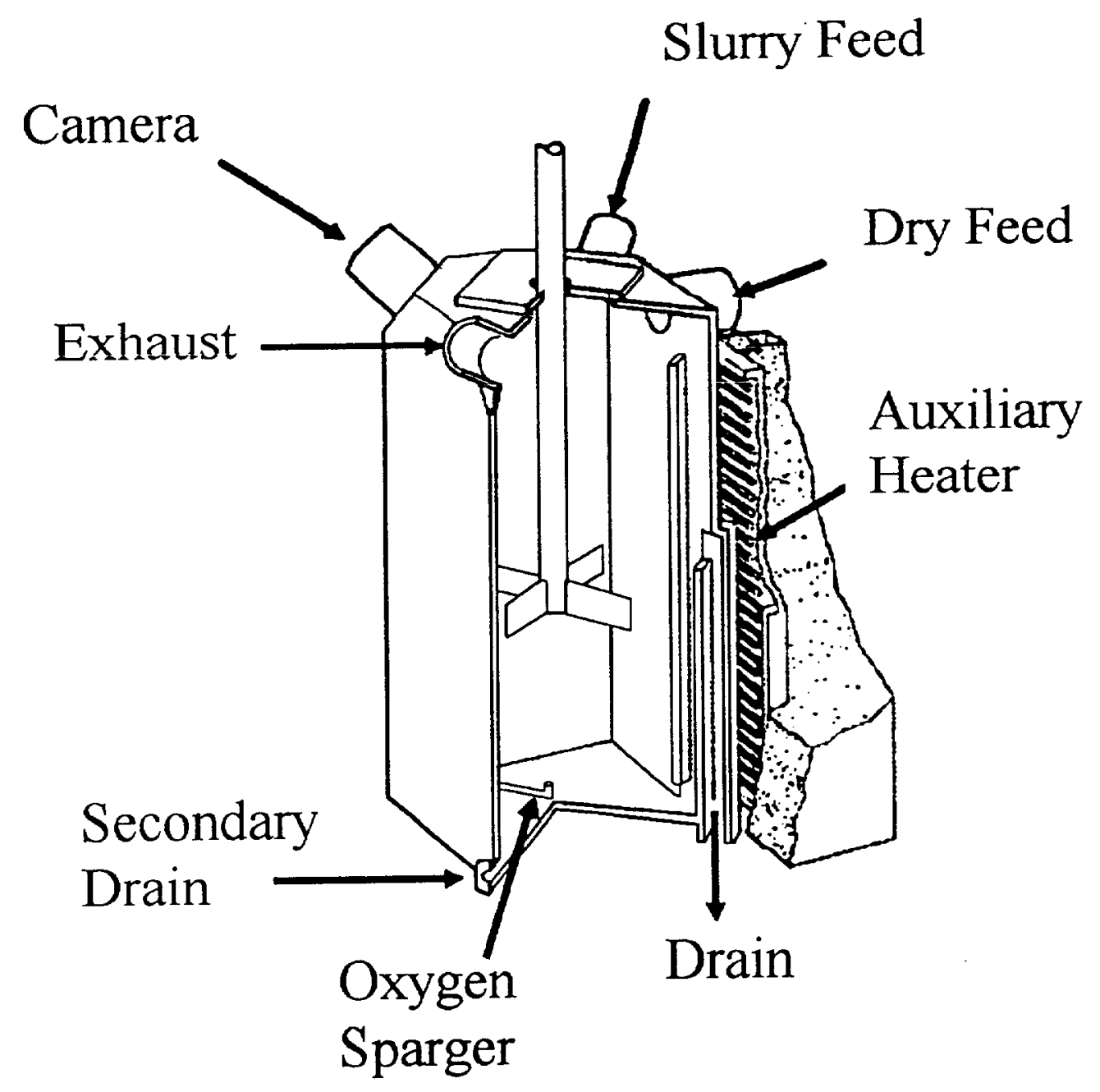

Fig. 1. Cutaway of Stir-Melter WV 0.25 with oxygen sparger. 


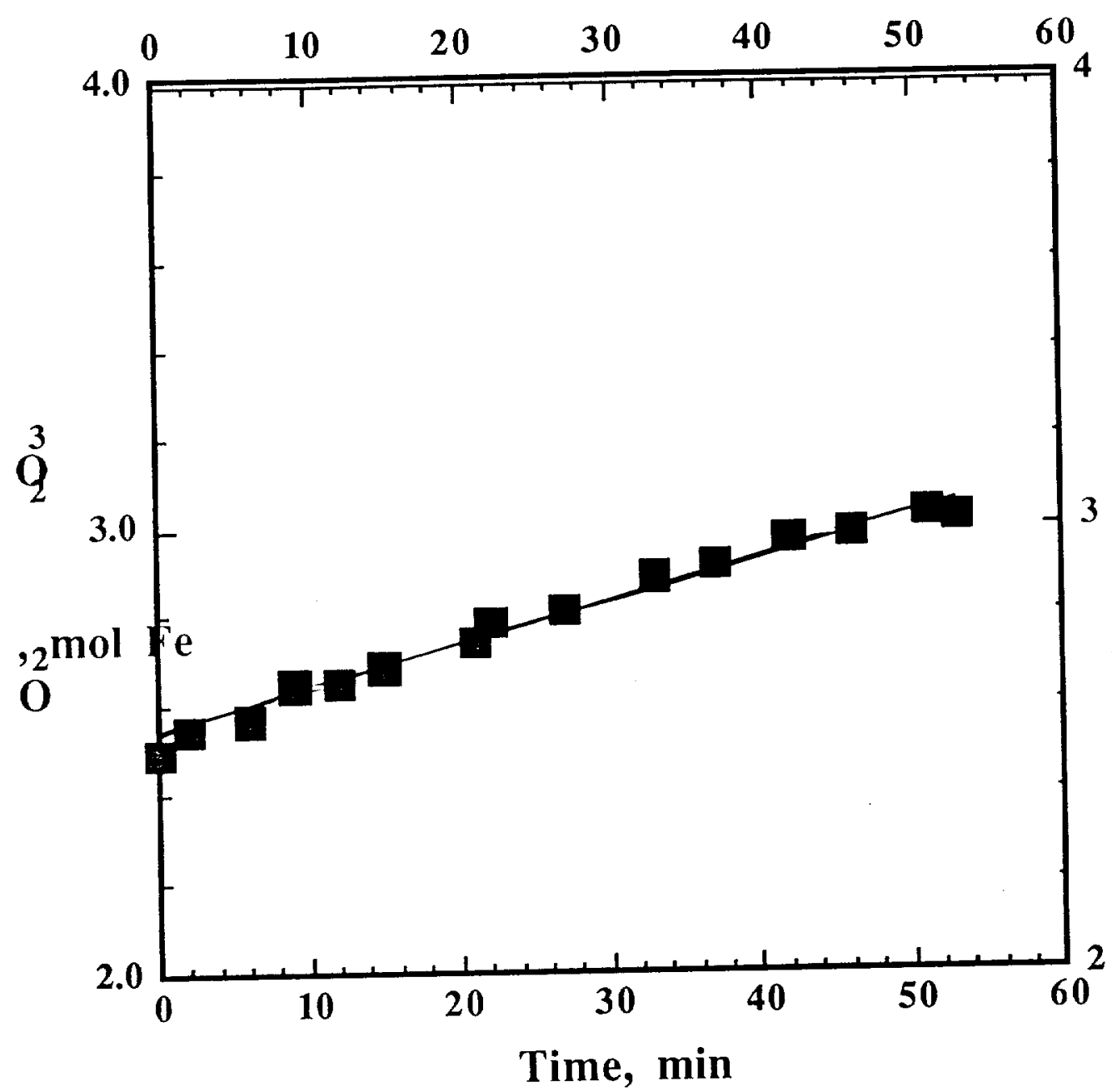

Fig. 2. Recovery curve for the continuous feed test. 
TABLE I

Analysis of the Feed Slurry on an Oxide Basis. ${ }^{1}$

\begin{tabular}{|l|c|c|}
\hline \multicolumn{1}{|c|}{ Oxide } & $\begin{array}{c}\text { Initial Sample, Mass } \\
\%\end{array}$ & $\begin{array}{c}\text { Final Sample, Mass } \\
\%\end{array}$ \\
\hline $\mathrm{Cs}_{2} \mathrm{O}$ & 0.26 & 0.55 \\
$\mathrm{~K}_{2} \mathrm{O}$ & 2.39 & 2.90 \\
$\mathrm{Li}_{2} \mathrm{O}$ & 4.85 & 4.50 \\
$\mathrm{Na}_{2} \mathrm{O}$ & 6.46 & 6.54 \\
$\mathrm{Al}_{2} \mathrm{O}_{3}$ & 2.95 & 3.35 \\
$\mathrm{~B}_{2} \mathrm{O}_{3}$ & 7.77 & 7.60 \\
$\mathrm{CaO}$ & 1.02 & 1.26 \\
$\mathrm{Cr}_{2} \mathrm{O}_{3}$ & 0.13 & 0.16 \\
$\mathrm{Fe}_{2} \mathrm{O}_{3}$ & 12.05 & 14.20 \\
$\mathrm{MgO}$ & 1.55 & 1.48 \\
$\mathrm{MnO}$ & 2.15 & 2.55 \\
$\mathrm{NiO}$ & 1.11 & 1.30 \\
$\mathrm{SiO}$ & $\underline{54.35}$ & $\underline{50.75}$ \\
Total & 97.04 & 97.14 \\
$\mathrm{Loss}$ on Ignition, \% & 63.00 & 66.50 \\
\hline
\end{tabular}

${ }^{1}$ Average of two samples. 
TABLE II

Analysis of Exit Glass on an Oxide Basis

\begin{tabular}{|l|r|r|r|r|}
\hline Oxide & 0 min & $627 \mathrm{~min}$ & $920 \mathrm{~min}$ & $1385 \mathrm{~min}$ \\
\hline $\mathrm{Cs}_{2} \mathrm{O}$ & $<0.01$ & 0.24 & 0.30 & 0.35 \\
$\mathrm{~K}_{2} \mathrm{O}$ & 2.43 & 2.70 & 2.76 & 2.76 \\
$\mathrm{Li}_{2} \mathrm{O}$ & 4.75 & 4.79 & 4.82 & 4.80 \\
$\mathrm{Na}_{2} \mathrm{O}$ & 6.69 & 6.69 & 6.73 & 6.76 \\
$\mathrm{Al}_{2} \mathrm{O}_{3}$ & 3.09 & 3.05 & 3.04 & 3.07 \\
$\mathrm{~B}_{2} \mathrm{O}_{3}$ & 7.90 & 7.75 & 7.76 & 7.80 \\
$\mathrm{CaO}$ & 1.70 & 1.24 & 1.23 & 1.24 \\
$\mathrm{Cr}_{2} \mathrm{O}_{3}$ & 0.19 & 0.17 & 0.17 & 0.17 \\
$\mathrm{Fe}_{2} \mathrm{O}_{3}$ & 12.00 & 12.25 & 12.50 & 12.57 \\
$\mathrm{MgO}_{\mathrm{MnO}}$ & 1.56 & 1.53 & 1.56 & 1.56 \\
$\mathrm{NiO}$ & 2.15 & 2.24 & 2.28 & 2.28 \\
$\mathrm{SiO}$ & 1.15 & 1.18 & 1.20 & 1.21 \\
$\mathrm{Total}$ & $\underline{54.10}$ & $\underline{52.70}$ & $\underline{53.55}$ & $\underline{53.67}$ \\
\hline
\end{tabular}

The values are averages of three samples taken at 0 and 1385 minutes and of replicate analyses on one sample taken at 627 and 920 minutes. 


\section{TABLE III}

Bubbler and Scrubber Cesium Concentrations

\begin{tabular}{|c|c|c|}
\hline $\begin{array}{c}\text { Time, } \\
\min \end{array}$ & $\begin{array}{c}\text { Bubbler Solution, } \\
(\mathrm{mg} \mathrm{Cs}) / \mathrm{L}\end{array}$ & $\begin{array}{c}\text { Scrubber Solution, } \\
(\mathrm{mg} \mathrm{Cs}) / \mathrm{L}\end{array}$ \\
\hline 0 & 0.0046 & $\mathrm{ND}^{1}$ \\
670 & 2.6942 & 0.2271 \\
1075 & 2.1131 & 0.4518 \\
1281 & 2.1617 & 0.5491 \\
1385 & 2.2278 & 0.6615 \\
\hline
\end{tabular}

${ }^{1}$ Not detected. 


\section{Westinghouse Savannah River Company Document Approval Sheet}

Document No WSRC-MS-97-0565

UC/C Number

\section{$4 C-721$}

Title

Vitrification of Cesium-Laden Organic lon Exchange Resin in a Stirred Melter

\begin{tabular}{|l|l|l|l}
\hline $\begin{array}{l}\text { Primary Author/Contact (Must be WSRC) } \\
\text { Connie Cicero-Herman }\end{array}$ & $\begin{array}{l}\text { Location } \\
773-41 \mathrm{~A}\end{array}$ & $\begin{array}{l}\text { Phone No. } \\
5-5306\end{array}$ & $\begin{array}{l}\text { Position } \\
\text { Ceramic Engineer }\end{array}$ \\
\hline $\begin{array}{l}\text { Organization Code } \\
\text { L3110 }\end{array}$ & $\begin{array}{l}\text { Organization (No Abbreviations) } \\
\text { Savannah River Technology Center }\end{array}$ \\
\hline
\end{tabular}

Other Authors

T.N. Sargent, T.J. Overcamp, and D.F. Bickford

\section{Keywords}

Vitrification, ion exchange resin, cesium

Intended Usage

$\square$ Report $\square$ Conference/Mtg/Presentation

$\square$ Software

$\triangle$ Other Journal

No. of Copies

4

\section{Reports}

$\square$ Quarterly

$\square$ Semiannual

$\square$ Annual

$\square$ Final

$\square$ Phase I

$\square$ Phase II

$\square$ Other

Report Dates thru

Retention Period Type of Record

$\otimes$ Lifetime $\square$ Nonpermanent

\section{Conference/Meeling/Presentation}

$\square$ Abstract

$\otimes$ Paper

$\square$ Technical $\square$ Published Proceedings $\otimes$ Other Joumal Article

Meeting/Journal Title (No Abbreviations)

Nuclear Technology

Contact: Dr. William F. Vogelsang, Editor

4 to 5 pages@\$135 per page

Meeting Address (City, State, Country)

555 North Kensington Ave., La Grange Park, IL 60526

Meeting Date(s)

$(\mathrm{m} / \mathrm{d} / \mathrm{y})$ thru

$(\mathrm{m} / \mathrm{d} / \mathrm{y})$

\section{Sponsor}

American Nuclear Society

I understand that for the information in this paper to be given external disbribution, approvals by both WSRC and, as appropriate, DOE-SR are required. Distribution (verbally or published) must be in accordance with policies set forth in WSRC management requirements and procedures

(MRP 3.25) and ipDOE-SR orders, ffod tho content of the extenal distribution must be limited to that actually approved.

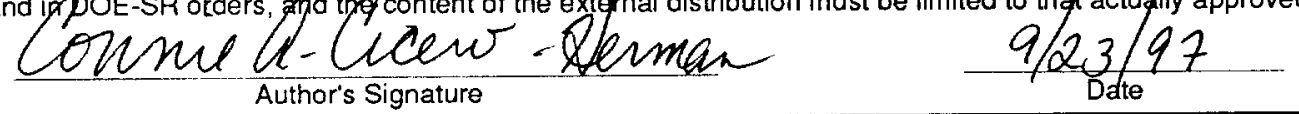

Approvals by Author's Organizatlon

Derivative Classifier

Classification

Topic

Distribution $\underline{X}$ Unlimited

Z Limited (Explain below)

Explanations

Manager's Name

C $/ 2$ Goteman

Manager's Signature

$2_{2}$

Date

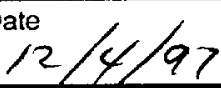

Classification Information (Ta ba completed by Classification Reviewer)
Classification (Check one for each)
Overall $\square \mathrm{S} \square \mathrm{C} \square$ UCNI $\square \mathrm{NU}$
Abstract $\square \mathrm{S} \square \mathrm{C} \square \mathrm{UCNI} \square$
Title $\square S \square C \square U C N I \square$
Cover Letter $\square S \square C \square$ UCNI $\square U$
WSRC Classification Pfficer's Name
CUASSIFCATION ANALYST
Classification Guide Topics

$$
\text { Ab Expert Contro/ concerns }
$$

\section{R. L Saname}
CuSSIFICATION ANGLYST
Plfande 12/10/97
\begin{tabular}{l|l} 
WSRC Classificatign Pfficer's Signature & Date \\
$12 / 2 / 0 / 97$
\end{tabular}

\section{Publications Uso Only}

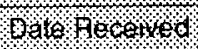

Pobicatoon oranos

016.010100 
Ms. W. F. Perrin, Technical Information Officer

U.S. Department of Energy - Savannah River Operations Office

Dear Ms. Perrin:

\section{REQUEST FOR APPROVAL. TO RELEASE SCIENTIFIC/TECHNICAL INFORMATION}

The attached document is submitted for classification and technical approvals for the purpose of external release. Please complete Part II of this letter and return the letter to the undersigned by $1 / 23 / 98$. The document has been reviewed for classification and export control by a WSRC Classification staff member and has been determined to be Unclassified.

I. DETAILS OF REQUEST FOR RELEASE

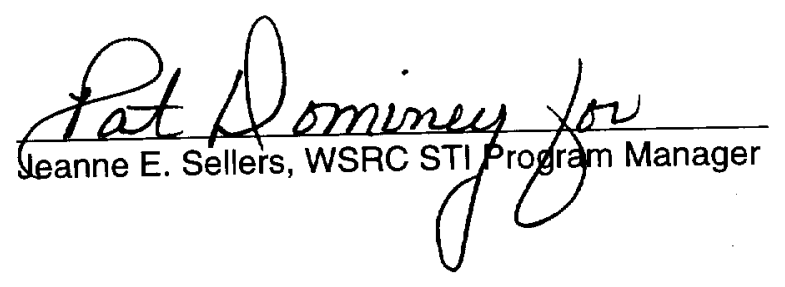

Document Number: WSRC-MS-97-0565

Author's Name: C. A Cicero-Herman

Location: $773-41 \mathrm{~A}$

Phone 5-5306

Department: SRTC

Document Title: Vitrification of Cesium-Laden Organic lon Exchange Resin in a Stirred Melter

Presentation/Publication:

Meeting/Journal: Nuclear Technology Journal

Location:

Meeting Date:

II. DOE-SR ACTION

Date Received by TIO
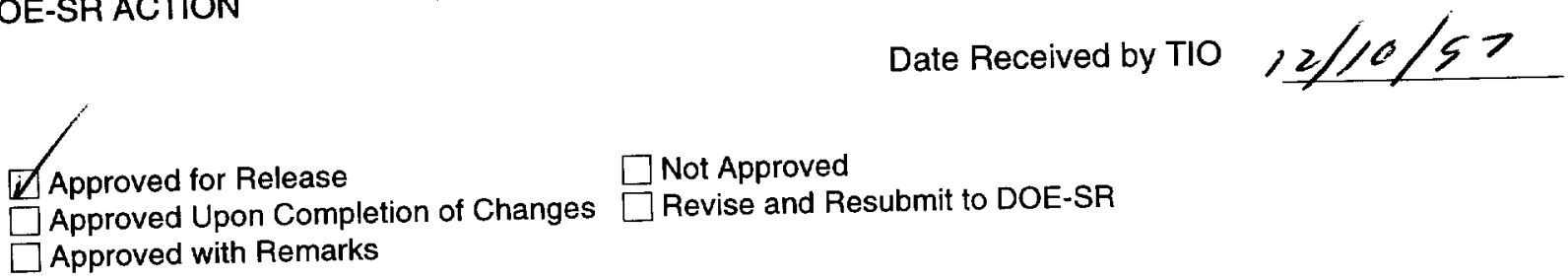

Remarks:
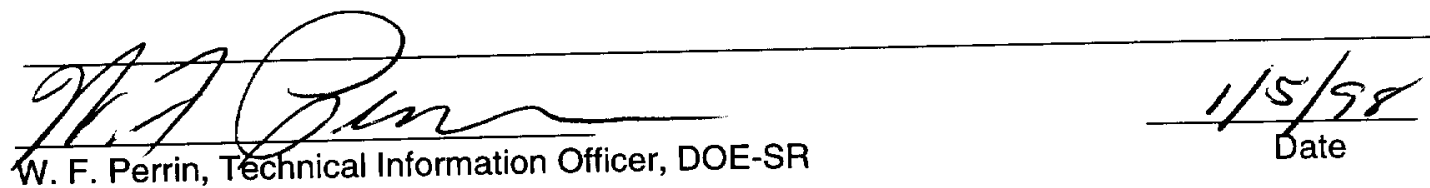
December 10, 1997

Mr. Murray Baxter

WSRC Intellectual Property Rights Office

Building 730-B

Savannah River Site

Aiken, SC 29808

Dear Mr. Baxter:

\section{REQUEST FOR APPROVAL TO RELEASE SCIENTIFIC/TECHNICAL INFORMATION (U)}

Please review the enclosed document for patent considerations. Please be advised that this document will be released within two weeks of the above date. Please complete the reponse section of this letter and return to the undersigned. Technical questions pertaining to the contents of this document should be addressed to the author or the manager. Questions concerning the processing of this document should be addressed to the WSRC STI Program office at (803) 725-4432.

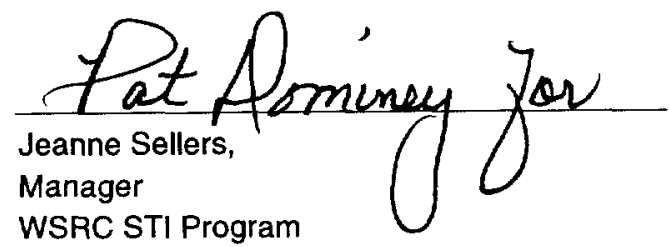

Document No. WSRC-MS-97-0565

Document Title Vitrification of Cesium-Laden Organic lon Exchange Resin in a Stirred Melter

Author C. A Cicero-Herman

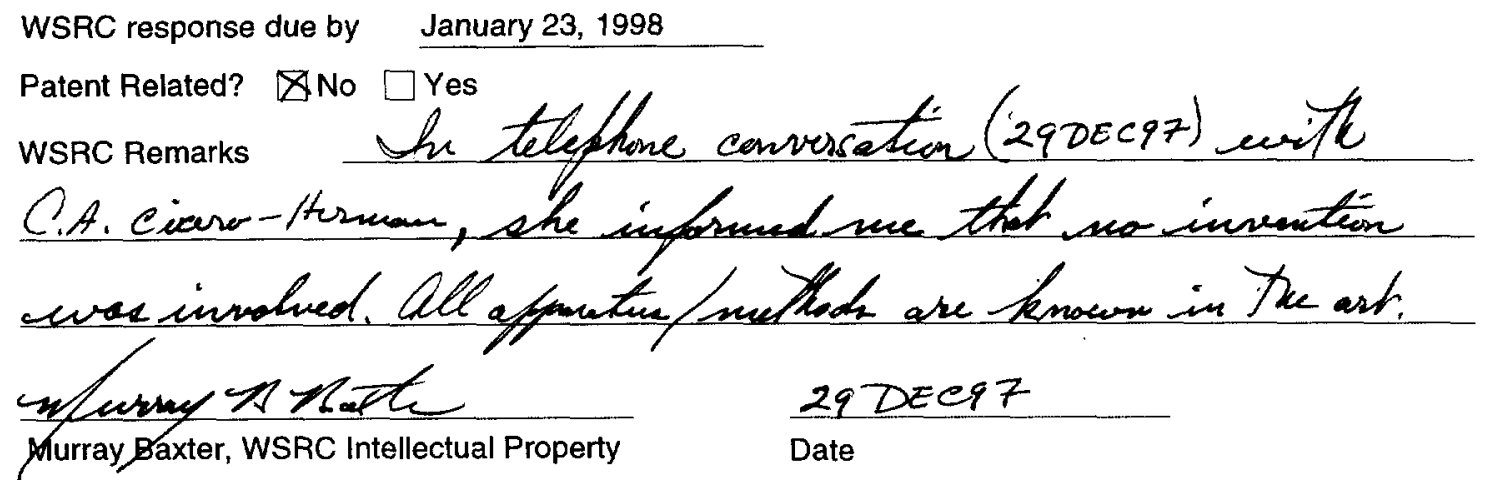




\section{PART I Information Product Identification}

\section{A. Identifiers}

1. Product/Report Nos.

WSRC-MS-97-0565

3. Title
2. Award/Contract Nos.

DE-AC09-96SR 18500

\section{Vitrification of Cesium-Laden Organic Ion Exchange Resin in a Stirred Melter}

(Grantees and Awardees skip to Part 1.B.)
4. Funding Office(s)
5. B\&R Code(s)
6. Project ID(s)

\section{DOE-SR}

\section{CRADA Nos.}

8. UC/C Category(ies)

9. Information Product Filename

UC-721

\section{B. Information Product Description}

1. Report

a. Type Quarterly

Serniannual

Annual

Final

Topical

Other (Specify)

b. Dates covered ( $m m / d d / y y y y)$

1

thru

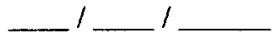

2. Conference

a. Type Conference paper - Published proceedings $\quad \checkmark$ Other (Specify)

b. Conference title (No abbreviations) _ Nuclear Technology Journal

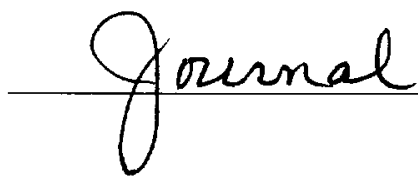

c. Conference location (city/state/country)

d. Conference dates $(\mathrm{mm} / \mathrm{dd} / \mathrm{y} y \mathrm{y} y)$

thru

e. Conference sponsor(s) American Nuclear Society

3. Software (Note: Additional forms are required. Follow instructions provided with this form.)

4. Other (Provide complete description.) 


\section{Information Product Format}

1. Product not submitted to OSTI (i.e., electronic version)

a. Location (FTP, URL, etc.)

b. File format SGML HTML Postscript PDF TIFFG4 Other (Specify)

c. SGML bibliographic record available With product Separately (Specify)

2. Product submitted to OSTI (i.e., electronic, paper, audiovisual, or computer medium)

a. Number of copies

one
(1) Twe for unclassified processing (2) copies for program unclassified distribution
(3) One for classified processing copies for standard classified distribution

$\longrightarrow(5)$

__ copies for OSTI to reproduce (Complete part C.3.)

(6) Other (Complete part C.3.)

b. SGML bibliographic record submitted to OSTI With product Separately (Specify)

c. Method of transmittal to OSTI

__ (1) Electronic (e.g., FTP, E-mail) (Note: Transmit only unclassified unlimited information not subject to access limitations over open systems, Contact OSTI for further information.)
(a) File format
SGML
HTML
Postscript PDF TIFFG4 Other (Specify)

___ (2) Computer medium (e.g., magnetic tape or diskette) (Complefe all. Provide a separate electronic or print abstract.)

(a) Quantity/type (Specify)

(b) Machine compatibility (Specify)

(c) Operating system (Specify)

(d) File format __ SGML__ HTML __ Postscript___ PDF___ TIFFG4 __ Other (Specify)

(3) Audiovisual Material (Complete all. Provide a separate electronic or print abstract.)

(a) Quantity/type (Specify)

(b) Machine compatibility (Specify)
(c) Sound
Yes __. No
(d) Color __ Yes No
(e) Playing time

\section{(4) Paper}

\section{Additional Instructions/explanations}

D. Contact (Person knowledgeable about the information product and its submission)

$\begin{array}{llll}\text { Name } & \text { Jeanne E. Sellers } & \text { Position Manager, STI _ Phone }(803) 725-2321 & \text { M } \\ \text { Organization } & \text { Westinghouse Savannah River Company } & \text { E-Mail __ jeanne.sellers@srs.gov }\end{array}$


(DOE/DOE Contractors complete; Grantees and Awardees complete as instructed by contracting officer)

A. Recommendations (Mark at least one)

1. Unlimited Announcement (Available to U.S. and non-U.S. public)

2. Unlimited Announcement/U.S. Dissemination Only

3. Classified (Standard announcement)

4. OpenNet

a. Non-NTIS Availability (Required if not available from NTIS)

(1) Accession Number

(2) Document Location

b. Field Office Acronym SR

c. Declassification date $(\mathrm{mm} / \mathrm{dd} / \mathrm{yyyy})$ ' Sanitized Never classified

5. Special Handling (Legal basis must be noted below.)

a. Copyrighted material All

b. Unclassified Controlled Nuclear Information (UCNI)

c. Export Control/ITAR/EAR

d. Temporary hold pending patent review

e. Translation of copyrighted material

f. Small Business Innovation Research (SBIR)

g. Small Business Technology Transfer (STTR)

h. Proprietary

i. Protected CRADA information

Release date $(\mathrm{mm} / \mathrm{dd} / \mathrm{y} y \mathrm{y})$ 1 l

j. Official Use Only (OUO)

k. Program-Directed Special Handling (Specify)

I. Other (Specify)

\section{B. Releasing Official}

1. Patent Clearance (Mark one)

_a. Submitted for DOE patent clearance

Date submitted (mm/dd/yyyy. 12/10/97

$\checkmark$ b. DOE patent clearance has been granted

_ C DOE patent clearance not required

\section{Released by}

Phone (803) 952-6558
Date $(m m d d / y y y)$

E-mail 


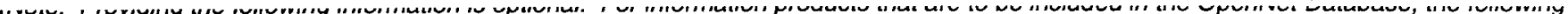

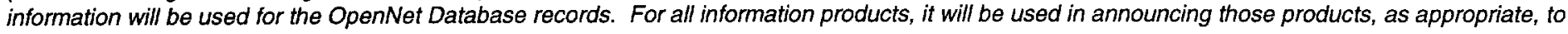
other parts of the DOE community.)

A. Personal Author/Affiliation C. A _ Cicero-Herman ; Westinghouse Savannah River Company

B. Performing Organization Westinghouse Savannah River $\quad$ SC US

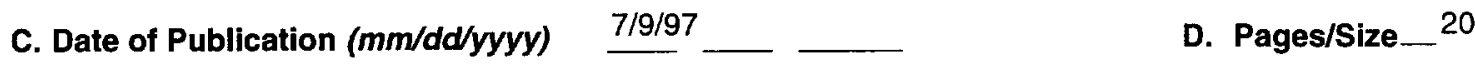

\section{E. Abstract}

The goal of this research was a feasibility study for vitrifying the organic ion exchange resin in a stirred-tank melter. Tests were conducted to determine the fate of cesium including the feed, exit glass, and offgas streams and to assess any impact of feeding the resin on the melter or its performance.

F. Subject Terms Vitrification, Ion Exchange Resins, Cesium

G. OpenNet Document Type $\square$ Audiovisual Material $\square$ Book $\square$ Conference $\square$ Correspondance $\square$ Data $\square$ Dissertation/Thesis H. OpenNet Document Categories

1. OpenNet Addressee 